\title{
TEKOÄLY JA TIETEELLISET KIRJASTOT
}

Tekoälyn ja sen keskeisen osa-alueen, koneoppimisen, historia juontaa vuosikymmenien taakse. Hypetermi tekoälystä on tullut viimeisen kymmenen vuoden aikana, kun laskentatehon kasvamisen myötä tekoälyn kehitystyö on laajentunut voimakkaasti.

Tekoälyn älykkyys perustuu todennäköisyyksien laskemiseen annetun datan pohjalta, ja algoritmin justeeraamiseen datan muuttuessa. Arkiset nykysovellukset ovat ehdotuksia käyttäjille: Ostit juuri muistitikun, ja käyttäjädatamme perusteella saattaisit olla kiinnostunut myös sankakuulokkeista tai säiliöpakastimesta.

Verkkomaailmassa tekoälysovelluksia on jo kaikkialla. Esimerkiksi hakukoneissa ja sosiaalisen median palveluissa käyttäytymistämme ohjataan varovaisin ehdotuksin tai suoranaisin käyttöä koskevin rajauksin. Siellä missä on paljon dataa, on ainakin potentiaalia tekoälysovelluksille. Tämän takia esimerkiksi kirjastot ovat luontevia kumppaneita teknologiayrityksille

Tekoälyllä on historiaa myös kirjastoissa. Heli Kautosen (Suomalaisen Kirjallisuuden Seura) ja Andrea Gasparinin (Oslon yliopiston kirjasto) Liber Quarterlyyn tekemässä laajassa - vielä julkaisemattomassa - kirjallisuuskatsauksessa varhaisin kirjaston tekoälyvisio oli vuodelta 1976 .

Tekoäly on mukana yhä useammissa tieteellisten kirjastojen palveluissa, mutta kenties vielä enemmän puhuttaa tekoälyn tulevaisuus kirjastoissa. Miten siihen pitäisi suhtautua?

Lyhyt, välitön vastaus voisi olla: pragmaattisesti ja ymmärtäen, mistä tekoälyssä on kyse. Kirjaston näkökulmasta tekoälyyn voi liittyä mahdol- lisuuksia esimerkiksi kokoelmatyön, palveluiden ja kirjastotilojen kehittämisessä, ja tämän voi nähdä luontevana osana digitaalisen kirjaston ja kirjastoautomatiikan jatkumoa.

Yhtä lailla on tärkeää ymmärtää tekoälyn ohjaamaan tai rajaamaan käyttöön liittyvät ongelmat, kuten erilaisten vinoumien ja stereotypioiden vahvistaminen. Tekoäly ei vain lue dataa, se myös tuottaa ja uusintaa todellisuutta.

Edellä kirjoitetut asiat nousevat esiin toisaallakin tässä lehdessä, sillä vuoden viimeinen numero on omistettu neljän artikkelin osalta tekoälylle. Otos kattaa kirjastokentän eri näkökulmista.

Heli Kautonen ja Pirjo Kangas johdattelevat teemaan, ja pohtivat kirjaston mahdollisia rooleja ja asennoitumisia suhteessa tekoälyyn. Taustalla on muun muassa tuo edellä mainittu kirjallisuuskatsaus.

Mikko Lappalainen ja kumppanit luovat pintaa syvemmän katsauksen koneoppimisen soveltamiseen kirjastotyön ytimessä eli sisällönkuvailussa, ja taustoittaa samalla automaattisen sisällönkuvailutyökalun Annifin rakentamista.

Kirsi Salmi, Jukka Englund ja Maarit Putous tarkastelevat tutkijoiden tiedonhakuun suunniteltua Iris.ai-tekoälyohjelmaa niin yrityksen ja kirjaston välisen kumppanuuden kuin käytännön tiedonhaunkin näkökulmasta.

Heidi Enwald ja Noora Hirvonen pohtivat tekoälyn lukutaitoa käsittelevässä artikkelissaan, millaisia näkökulmia tekoälyteknologioiden käytön ja vaikutusten tunnistamiseen liittyy kirjastojen kannalta. 